\title{
Fen Bilimleri Öğretmen Adaylarının Sosyobilimsel Argümantasyon Kalitelerinin İncelenmesi: Konu Bağlamının Etkisi
}

\author{
Ali Yiğit KUTLUCA*, Abdullah AYDIN \\ İstanbul Aydın Üniversitesi, İstanbul, TÜRKİYE; Kastamonu Üniversitesi, Kastamonu, \\ TÜRKIYY
}

Makale Gönderme Tarihi: 25.10.2016

Makale Kabul Tarihi: 01.03.2017

$\ddot{O}_{z e t}$ - Bu araştırmanın amacı, fen bilimleri öğretmen adaylarının sosyobilimsel argümantasyon kalitelerinin tartışılan konu bağlamına göre değişimini incelemektir. Araştırmaya, üçüncü sınıfta öğrenim gören 27 fen bilimleri öğretmen adayı katılmıştır. Araştırmaya katılan fen bilimleri öğretmen adayları içerisinden, 11 hafta süren uygulama sürecinin başında bilimin doğası anlayışlarına göre seçilen 12 katılımcı, dörder kişilik üç gruba ayrılmışlardır. Gruplarda yer alan öğretmen adayları, sosyobilimsel argümantasyon sürecinde 'elektrikli otomobil üretimi', 'cep telefonları insan hayatını tehdit ediyor' ve 'altın pirinç' isimli senaryolar aracılığıyla argümanlar oluşturmuşlardır. Grupların bu senaryolar doğrultusunda yaptıkları argümantasyonların nitel analizi metodolojik bir araç yardımıyla çözümlenirken, konu bağlamının sosyobilimsel argümantasyon kalitesi üzerindeki etkisinin istatistiksel anlamlılığını belirlemek için ise SPSS 20 paket programında bulunan Kruskal Wallis-H testi kullanılmıştır. Nitel ve nicel veri analizlerinden elde edilen bulgular, en kaliteli argümantasyonların 'altın pirinç' isimli senaryo bağlamında yapıldığını göstermiştir. En düşük argümantasyon kalitesinin tespit edildiği senaryo bağlamı ise 'cep telefonları insan hayatını tehdit ediyor' adlı senaryodur. Bu araştırmada ulaşılan sonuçlar, ilgili literatür doğrultusunda tartışılmıştır.

Anahtar kelimeler: Fen bilimleri öğretmen adayı, argümantasyon, sosyobilimsel argümantasyon kalitesi, konu bağlamı.

\section{Genişletilmiş Özet}

\footnotetext{
* İletişim: Yrd. Doç. Dr. Ali Yigit KUTLUCA, Sınıf Öğretmenliği Ana Bilim Dalı, Temel eğitim Bölümü, Eğitim Fakültesi, İstanbul Aydın Üniversitesi, İstanbul, TÜRKIYE.

E-posta: aliyigit8834@gmail.com

Not: Bu çalışmanın bir kısmı, 12. Ulusal Fen Bilimleri ve Matematik Eğitimi Kongresinde sözlü bildiri olarak sunulmuştur.
} 


\section{Giriş}

Çağdaş fen eğitiminin en temel amaçlarından biri öğrencilerin sosyobilimsel konular hakkında nitelikli birer karar verici ve bilim okuryazarı olmalarını sağlamaktır (Dawson \& Venville, 2010). Bu bağlamda, öğrencilerin bilimsel ve sosyobilimsel aktivitelere katılarak epistemik ve kavramsal anlayışlarının geliştirilmesini sağlayan bir araç olarak argümantasyonun fen eğitimine dâhil edilmesi; çağdaş fen eğitimi programları için özel bir ilgi alanına dönüşmüştür. Söz konusu programlar (AAAS, 2001; NRC, 2013; MEB, 2013); fen eğitiminin öğrencilerin bilimin doğasını, bilim insanlarının bilgiye nasıl ulaştıklarını ve bilimsel metotları anlamalarına yardım etme sorumluluğuna sahip olmaları gerektiğini vurgulamaktadırlar. Bu hedefi başarmak için ise özellikle öğretmenlere büyük roller düşmektedir. Sosyobilimsel konuların fen eğitimine dâhil edilmesi ve öğrenci katılımı bağlamında uzun süreden beri birçok araştırma yapıllmıs ve halen de yapılmaya devam edilmektedir (Örn; Kara, 2012; Herman, 2015). Bu araştırmalarda sosyobilimsel argümantasyon kalitesi veya akıl yürütmelerin niteliği; kişisel deneyimler (Albe, 2008), bilimin doğası anlayışları/kavramsallaştırmaları (Herman, 2015), kültürel bakış açıları (Sadler \& Donnelly, 2006), alan bilgisi (Sadler \& Fowler, 2006) ve epistemolojik anlayışlar (Liu, Lin, \& Tsai, 2011) gibi birçok faktör açısından incelenmiştir. Fakat konu bağlamının sosyobilimsel argümantasyon kalitesi üzerindeki olası etkisini incelemeye yönelik sınırlı sayıda çalışma vardır (örn; Molinatti, Girault, \& Hammond, 2010; Topçu, Sadler, \& Y1lmaz-Tüzün, 2010). Bununla birlikte araştırma bulguları arasında tutarlılık bulunmamaktadır (e.g. Albe, 2008; Dawson \& Venville, 2010). Bu rasyoneller doğrultusunda bu araştırmanın amacı, fen bilimleri öğretmen adaylarının sosyobilimsel argümantasyon kalitelerinin tartışılan konu bağlamına göre değişimini incelemektir.

\section{Metodoloji}

$\mathrm{Bu}$ araştırma, nitel ve nicel araştırma desenlerini birlikte barındıran karma yöntem (mixed type) türünden bir araştırmadır. Bu çalışmada ise katılımcılara ilk aşama olarak Argümantasyon Açısından Bilimin Doğası (AABD) Testi uygulanarak nicel veri, sonrasında ikinci aşama olarak ise sosyobilimsel argümantasyon süreci ile nitel veri toplanmıştır. Araştırma, bir devlet üniversitesinin fen bilgisi eğitimi anabilim dalında öğrenim gören 27 (23 kız, 4 erkek), üçüncü sınıf fen bilimleri öğretmen adayının içinden bilimin doğası anlayışlarına göre seçilen 12 fen bilimleri öğretmen adayı ile gerçekleştirilmiştir. Araştırmaya katılan öğretmen adayları, sosyobilimsel argümantasyon sürecinde "elektrikli otomobil üretimi”, "cep telefonları insan hayatını tehdit ediyor" ve "altın pirinç" isimli senaryolar aracılığıla argümanlar 
oluşturmuşlardır. Katılımcıların bu senaryolar doğrultusunda yaptıkları argümantasyonlar Erduran, Simon, \& Osborne (2004) tarafından geliştirilen metodolojik bir araç yardımıyla nitel olarak analiz edilmiştir. Buna ek olarak konu bağlamının sosyobilimsel argümantasyon kalitesi üzerindeki etkisinin istatistiksel anlamlılı̆̆ını belirlemek için SPSS 20 paket programında bulunan Kruskal Wallis-H testi kullanılmıştır.

\section{Sonuç ve Tartışma}

Nitel ve nicel veri analizlerinden elde edilen bulgular, en kaliteli argümantasyonların "altın pirinç” isimli senaryo bağlamında yapıldığını göstermiştir. En düşük argümantasyon kalitesinin tespit edildiği senaryo bağlamı ise "cep telefonları insan hayatını tehdit ediyor" adlı senaryodur. Fen bilimleri öğretmen adaylarının sosyobilimsel argümantasyon kalitesinin konu bağlamına göre değişimini inceleme amaçlı yapılan bu çalışmada, söz konusu iki değişken arasında anlamlı bir farklılık bulunduğu tespit edilmiştir. Bu sonuç ve mevcut literatürde belirtilenler, bu araştırma alanına yönelik daha fazla çalışılma yapılması gerektiğini ortaya çıkarmaktadır. $\mathrm{Bu}$ nedenle özellikle de ulusal literatüre katkı sağlamak için, bu çalışmanın bağlamı aynı kalmak kaydıyla fen bilgisi öğretmen adayları ile daha çok araştırma yapılabilir. 


\title{
The Investigation of Pre-service Science Teachers' Socio- scientific Argumentation Quality: the Influence of the Context
}

\author{
Ali Yigit KUTLUCA ${ }^{\dagger}$ \& Abdullah AYDIN \\ Istanbul Aydin University, Istanbul, TURKEY; Kastamonu University, \\ Kastamonu, TURKEY
}

Received : 25.10.2016

Accepted : 01.03.2017

\begin{abstract}
The aim of this study is to investigate the change of pre-service science teachers' argumentation quality in relation to the context of argumentation. 27 third class pre-service science teachers participated in this study. 12 participants were divided into three groups, each containing 4 participants, according to their nature of science understandings at the beginning of the implementation process, which lasted for 11 weeks. These pre-service science teachers mounted argumentations in relation to the argumentation scenarios like 'production of electric cars', 'cell phones are threatening human life', and 'golden rice' in the process of argumentation. While the qualitative analysis of their argumentations was resolved with the help of a methodological tool; Kruskal Wallis$\mathrm{H}$ test, present in SPSS 20 package, was used in order to determine the statistical significance of the contextual influence on socio-scientific argumentation quality. According to the results of qualitative and quantitative analyses the best quality argumentations were formed within the context of 'golden rice' scenario. On the other hand the lowest quality argumentations were formed within the context of 'cell phones are threatening human life' scenario. The results of this study were discussed within the context of related literature.
\end{abstract}

Key words: Preservice science teacher, argumentation, socioscientific argumentation quality, issue context

\section{Introduction}

One of the primary functions of contemporary science education is to enable students to make conscious decisions about the socio-scientific issues in their lives and to use their scientific understandings within the argumentation processes that they may encounter in their daily lives (Dawson \& Venville, 2010). In relation to the mentioned purpose, socio-scientific issues that encourage scientific literacy enable the development of epistemic awareness with

\footnotetext{
${ }^{\dagger}$ Corresponding Author: Ali Yigit KUTLUCA, Asist. Prof. Dr., Department of Classroom Teaching, Elementary Education, Faculty of Education, Istanbul Aydin University, Istanbul, TURKEY
}

\section{E-mail: aliyigit8834@gmail.com}

Note: A portion of this study were presented as oral presentation in the 12. National Science and Mathematical Education Congress. 
the use of scientific content by evaluating information and analysis (Zeidler, Sadler, Simmons, $\&$ Howes, 2005). In relation to this, in a lot of studies socio-scientific issues were predicted that they would provide a rich learning and teaching environment since they have technological, methodological and conceptual contradictions (e.g., Venville \& Dawson 2010; Iordanou \& Constantinou, 2014). Along with that the inclusion of argumentation into science education as an instrument, which include students to scientific and socio-scientific activities, provides students to improve their epistemological and cognitive development has become a specialty for the contemporary education programs. These mentioned programs (AAAS, 2001; NRC, 2013; MEB, 2013) emphasize that science education must undertake the responsibility to support students to understand the nature of science, scientific methods, and the way scientists reach information. Since they are the people who can provide environments where students can use their critical thinking and reasoning abilities in science classes and labs (Driver, Newton, \& Osborne, 2000, Simon \& Johnson, 2008). The main purpose of science education, according to the constructivist philosophy which has been in practice in Turkey since 2005, is to help students to obtain skills rather than to give them scientific knowledge (MEB, 2013). But, no matter how perfectly are the programs prepared, there is always a big responsibility for the teachers. Therefore, it is necessary for teacher candidates to be educated on related issues before the students. If the pre-service science teachers have the chance to obtain education on socioscientific context and argumentation process, not only it will be more likely for them to include these processes to their teaching, but also they will have more developed pedagogic skills (Zohar, 2008; Nielsen, 2012). There have been lots of studies conducted on the inclusion of socio-scientific issues into science education and student participation for a long time and these studies still continue to be conducted (e.g., Kara, 2012, Kırbă̆ Zengin, Keçeci, \& Kur1lmazkaya, 2012; Herman, 2015). In this study socio-scientific argumentation quality and reasoning quality were examined from a lot of aspects such as; personal experiences (Albe, 2008), nature of science understandings/conceptualizations (Köseoğlu, Tümay, \& Üstün, 2010), cultural point of views (Sadler \& Donnelly, 2006), subject knowledge (Sadler \& Fowler, 2006), and epistemological understandings (Liu, Lin, \& Tsai, 2011). Dawson (2015), Zeidler and Nichols (2009), and so many researchers working on socio-scientific issues stated that the proofs used in the context of socio-scientific issues have less accuracy than the proofs used in scientific context, and also they have a more changeable nature; so they claimed that in order to supply more specific arguments, it is necessary to stick to the nature of argumentation. This mentioned situation shows that contextual issue has a direct or indirect influence in the process of argumentation. Albe (2008), in a phenomenological study which is grounded on one of these 
rationales, investigated the socio-scientific argumentations that were mounted by 12 high school students on the effects of cellphones on our lives. The researcher determined that students' awareness of the epistemological nature of the context and their social interaction within the group influenced their elaboration degree of their arguments. The researcher, also, claimed that the contextual knowledge did not have much influence on the formation of arguments; instead he asserted social and cultural nature of science to be more influential. In the case study conducted by Dowson and Venville (2010) with the participation of 910 secondary school students, it was aimed to determine the influential factors behind the students' participation to the socio-scientific argumentation processes. The researchers determined, by classroom observations, interviews with students, analyzation of students' written arguments about cystic fibrosis and genetically modified tomatoes, that students' participation to the socioscientific argumentation processes have been affected by four important factors: teacher's role in the facilitation of whole class discussions, the usage of written frame, socio-scientific context and student's role. Another study on the influence of context on the socio-scientific argumentation quality was conducted by Molinatti, Girault and Hammond (2010). The researchers investigated the influence of socio-scientific context on argumentation and decision making in their study, which was conducted with 196 high school students. The results of this study, which analyzed the argumentations which were formed within the contexts of stem cell applications and gene therapy, showed that the context influenced both the participation to the argumentation process and the concepts related to the nature of science. The researchers showed that the nature of science understandings and argumentation qualities may not be at same levels within different contexts. Also, Topçu, Sadler and Yılmaz-Tüzün (2010) included 39 preservice science teachers to their study, which they investigated the influence of the context on the quality of argumentation in socio-scientific issues; and concluded that the participants' ideas that they had in the decision making process were formed within the frame of three reasoning patterns; rationalist, emotional, and intuitional. Besides, it was determined that the decisions of pre-service teachers were not related to the context; and their decisions were shaped by four other factors. These factors were personal experiences, socialfactors, moral-ethical issues, and technological concerns. Lastly, Khishfe (2012b) investigated the relationship between students' nature of science understandings and their argumentation skills within the socio-scientific context in her study which was conducted with 219 high school students. The researcher determined the relationship between the argumentation skills and nature of science understandings after her quantitative analyses and concluded that this result was also confirmed 
by qualitative analyses. In addition to this she also reached two basic findings in respect to the nature of science teaching and argumentation skills. The first of these is the role of opposing arguments and the other one is the familiarity of the discussed subject, already possessed knowledge of the subject, and being aware of the contextual factors including personal involvement rate. The researcher presented two different scenarios in the contexts of genetically modified organisms and water fluoridation; and she determined that the context resulted in different outcomes in relation to nature of science understandings and argumentation skills. While it has been seen that studies conducted on the inclusion of socio-scientific issues to the science education is very limited in Turkey with regard to international literatüre (e.g., Topçu, Muğaloğlu, \& Güven, 2014; Eş, Mercan, \& Ayas, 2016); no conducted study was found on the basis of the relationship between the context and socio-scientific argumentation. Both this rationale and the inconsistency of results conducted on the relationship of context and socioscientific argumentation quality in literature evoke the need for further studies on the subject. In addition, pre-service science teachers to have the chance to obtain education on socioscientific context and argumentation process will more likely to cause them include these processes in their teaching careers and also they will have more developed pedagogic skills. This, alone, can be accepted as another rationale. In the light of the rationales mentioned, the aim of this study is to investigate the change of pre-service science teachers' argumentation quality in relation to the context of argumentation.

\section{Method}

This is a mixed type study which combines quantitative and qualitative study patterns Onwuegbuzie and Leech (2004) stated that the aim of mixed type research is not to verify or support an idea in many ways, but to expand the subject's understanding of the event. According to this, the mixed type presents a comprehensive, pluralist, complementary and eclectic approach in order to provide choice of method and to enable the researcher to prepare designs for the study. By using a mixed type method in this study, it was aimed to provide the data triangulation, which is the whole body of efforts made to increase cogency (Y1ldirim \& Şimşek, 2008). Along with that by detailing the collected data, it was aimed to reach the complementary principle purposed by Giannakaki (2005). Acording to Giannakaki the complementary principle is to have rich and detailed data by measuring the problem from different perspectives. In this study which has both qualitative and quantitative data, the quantitative data have been used more than the qualitative data. This research method is called explanatory mixed method (Cresswell, 2008; Sullivan, 2009). It this research design, in the first 
phase quantitative data are gathered, and then in the second phase in order to expand and explain these quantitative data, qualitative data are gathered (Cresswell, 2008). In this study, in the first phase in order to gather quantitative data, participants were tested with NSAAQ Test and in the second phase qualitative data were gathered by socio-scientific argumentation process. You can see more clearly that which data collection, implementation, and data analysis processes were followed in Figure 1.

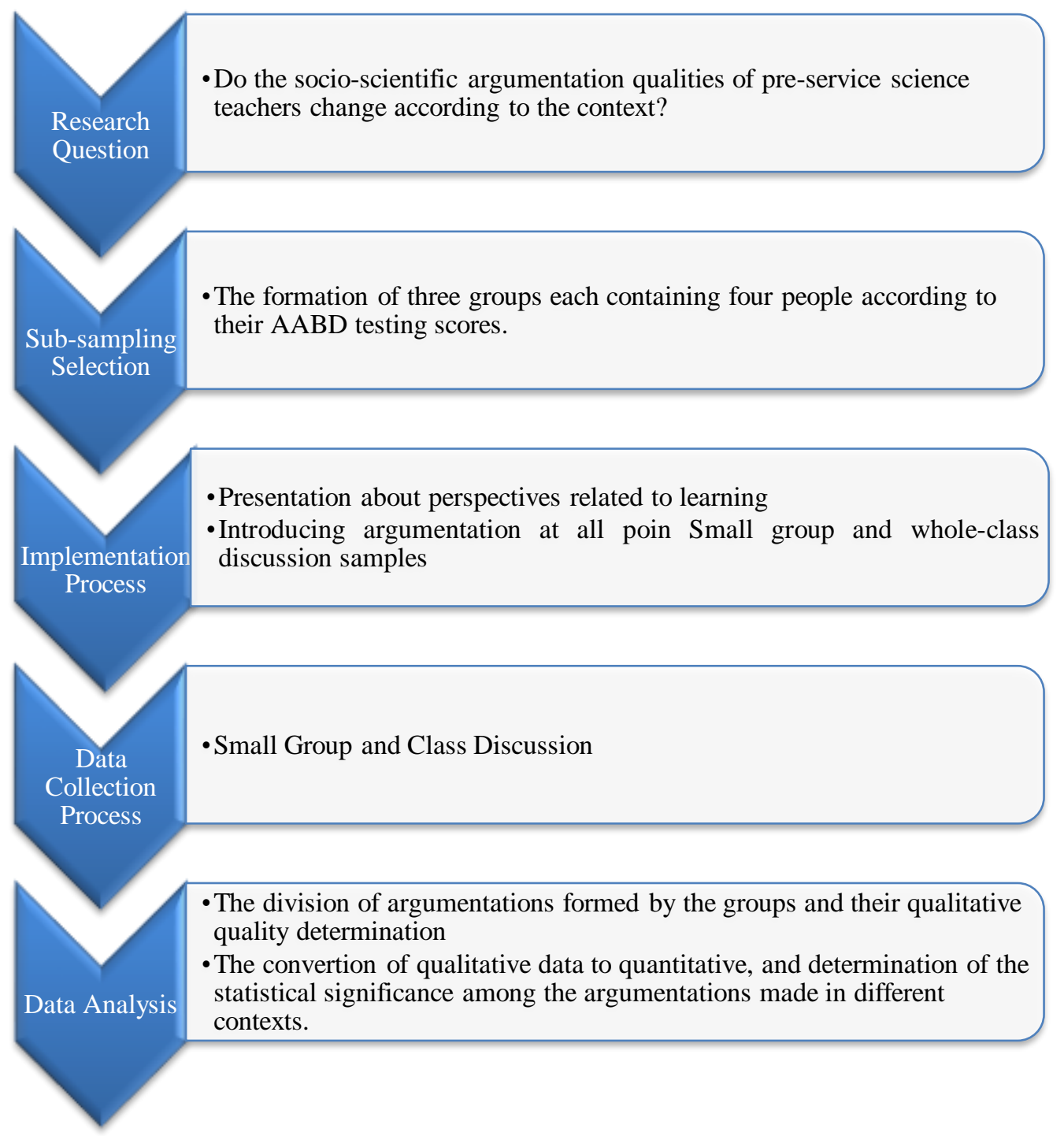

Figure 1 Steps Followed During the Implementation, Data collection and data Analysis Processes 


\section{Participants}

This study was conducted with 12 participants whom were chosen according to their nature of science understandings among 27 third grade pre-service science teachers $(23$ females and 4 males) of a state university in Turkey. Information about the participants is given in Table 1.

Table 1 Information about Low, Middle and High Group Participants

\begin{tabular}{|c|c|c|c|}
\hline \multicolumn{2}{|c|}{ GROUP PARTICIPANTS } & \multirow{2}{*}{$\begin{array}{c}\text { GENDER } \\
\mathrm{F}\end{array}$} & \multirow{2}{*}{$\begin{array}{c}\text { NSAAQ TEST SCORE } \\
94.0\end{array}$} \\
\hline \multirow{4}{*}{$\underset{0}{0}$} & $\mathrm{~A}_{1}$ & & \\
\hline & $\mathrm{B}_{1}$ & F & 92.0 \\
\hline & $\mathrm{C}_{1}$ & $\mathrm{~F}$ & 92.0 \\
\hline & $\mathrm{D}_{1}$ & $\mathrm{M}$ & 92.0 \\
\hline \multirow{4}{*}{$\underset{0}{0}$} & $\mathrm{~A}_{2}$ & $\mathrm{~F}$ & 85.0 \\
\hline & $\mathrm{B}_{2}$ & F & 85.0 \\
\hline & $\mathrm{C}_{2}$ & F & 85.0 \\
\hline & $\mathrm{D}_{2}$ & $\mathrm{~F}$ & 85.0 \\
\hline \multirow{4}{*}{ 家 } & $\mathrm{A}_{3}$ & $\mathrm{~F}$ & 74.0 \\
\hline & $\mathrm{B}_{3}$ & $\mathrm{~F}$ & 73.0 \\
\hline & $\mathrm{C}_{3}$ & $\mathrm{M}$ & 72.0 \\
\hline & $D_{3}$ & $\mathrm{M}$ & 70.0 \\
\hline
\end{tabular}

\section{Group Division Process}

There are three different classes (A-B-C) in this university's education faculty's science education program. The class on which the study was conducted was chosen with simple random sampling method. 27 pre-service science teachers were divided into three groups, which were homogeneous within group and heterogeneous intergroup, each consisting four participants whom were chosen according to their NSAAQ test results. Groups were chosen with maximum variety method of the sampling methods. The reason of the inclusion of these 12 participants, whom were chosen among the 27 participants, was to provide the sampling, which the study would be carried on, to consist homogenous but different situations. The rationale behind the inclusion of the participants to the process after they had been divided into groups according to their nature of science understandings is:

Students may need to know the context of the problem that they encounter, and understandings related to how scientists evaluate claims in order to make qualified reasoning and make effective judgements (Zeidler et al., 2005; Sadler, Chambers, \& Zeidler, 2004; Liu, et al., 2011).

For this reason it is necessary to consider every student's nature of science and epistemological understandings. In this regard, the ways followed for the formation of subgroups are as below.

1. AABD test was implemented on all of the 27 participants. 
2. After the determination of arithmetic mean of the participants and standard deviation, the formulas below were used (Fraenkel, Wallen, \& Hyun, 2006).

$$
\begin{gathered}
\text { Arithmetic Mean }+\frac{\text { Standard Deviation }}{2}<\text { GROUP I } \\
\text { Arithmetic Mean }-\frac{\text { Standard Deviation }}{2}>\text { GROUP III } \\
\text { GROUP III }>\text { GROUP II }>\text { GROUP I }
\end{gathered}
$$

As it is seen in the formulas; the scores higher than the addition of half of the arithmetic mean and standard deviation show the members of Group I, the scores lower than the difference of arithmetic mean and standard deviation show the members of Group III, and lastly the scores between these two groups show the members of Group II. Other groups consisting four members were formed according to their scores of NSAAQ test with the preservice science teachers who are not in Group I, II, and III. Totally seven groups were formed with the 27 participants. By this way, the researcher included all the participants to the argumentation process. Members of the subgroups were not informed about the data collection. Thus, not only their data stayed untouched, but also they actively participated in the process.

\section{Data Collection Tools}

The Nature of Science as Argumentation Questionnaire NSAAQ Test: The NSAAQ test, which was developed by Sampson and Clark (2006) and adapted into Turkish by Çetin, Erduran and Kaya (2010), was taken by all the participants and the participants were divided into subgroups according to their nay-ture of science understandings. In order to determine the reliability coefficient the NSAAQ test was performed on 254 third grade science education program students of five different universities, and the Cronbach Alpha reliability co-efficient of the test was calculated to be 0,79 . This value proves the reliability of the test (Fraenkel et al., 2006).

Weekly Activities: There are 12 scenarios, which were prepared according to nature of science and in consideration of certain fictional elements and contemporary subjects, present in the activity booklet which was given to the participants at the begining of the 11 week long process. The socio-scientific contexts used in this study help the participants to easily refer to scientific ideas and along with that they also consist encouragaging elements for the consideration of informal aspects like cultural, ethical, and social anxieties (e.g. Khishfe, 2012a; Zeidler et al., 2005). For the approval of the scenarios, in terms of issue context, argumentation, nature of 
science and language adequacy, three different researchers who are experts in their fields were consulted. Scenarios were finalized after the expert opinions. The change of socio-scientific argumentation quality in relation to the contextual change was evaluated with the help of 'Electric Car Production', 'Smart phones Are Threatening Human Life', 'Golden Rice' scenarios which were presented in the booklet. The selection reasons of these scenarios can be stated as:

- Their group discussion times were longer than the others; so the data can be seen more clearly,

- Active participation of pre-service science teachers,

- The willigness of the participants during the process of argumentation (Osborne, Erduran, \& Simon, 2004).

Detailed information about the content of the scenarios is given in Table 2.

Table 2 Socio-scientific Argumentation Scenarios

\begin{tabular}{cl}
\hline $\begin{array}{c}\text { NAME OF THE } \\
\text { SCENARIO }\end{array}$ & \multicolumn{1}{c}{ INFORMATION } \\
\hline Electric Car Production & $\begin{array}{l}\text { This scenario, which was written by Salvato and Testa (2012), has a } \\
\text { contradictory plot about the energy resources of electric cars and gasoline- } \\
\text { powered cars and their effects on nature. This scenario was adapted to Turkish } \\
\text { for this study. }\end{array}$ \\
$\begin{array}{c}\text { This scenario discusses harms and benefits of cell phones, which are the mostly } \\
\text { Threatening Human Life }\end{array}$ & $\begin{array}{l}\text { used technological gadgets of our time, all together. This scenario, which was } \\
\text { written by Salvato and Testa (2012), was used as an adaptation to Turkish. } \\
\text { This scenario contains a plot in which two groups of scientists defend } \\
\text { contradictory knowledge about 'Golden Rice' which is a genetically mutated } \\
\text { product developed against vitamin A deficiency. This scenario, which was } \\
\text { written by Khishfe (2012), was adapted to Turkish. }\end{array}$ \\
\hline
\end{tabular}

Data Analysis

The data collected in order to determine the changes of pre-service science teachers' argumentation quality in relation to the context of argumentation were analyzed by qualitative and quantitative analysis methods. In the study, at first NSAAQ scores were analyzed quantitatively and participants were divided into subgroups. And then, argumentations formed during the process of argumentation were qualitatively analyzed with a methodological tool which was developed by Erduran et al. (2004) in accordance with the Toulmin Model Argumentation (Table 3). 
Table 3

Argumentation Assesing Tool

\begin{tabular}{clc}
\hline $\begin{array}{c}\text { Argumentation } \\
\text { Level }\end{array}$ & \multicolumn{1}{c}{ CONTENT } & SCORE \\
\hline Level I & $\begin{array}{l}\text { Argumentation consists of arguments that are a simple claim versus a counter- } \\
\text { claim or a claim versus a claim. }\end{array}$ & 1 \\
Level II & $\begin{array}{l}\text { Argumentation has arguments consisting of a claim versus a claim with either } \\
\text { data, warrants, or backings but do not contain any rebuttals. }\end{array}$ & 2 \\
Level III & $\begin{array}{l}\text { Argumentation has arguments with a series of claims or counter-claims with } \\
\text { either data, warrants, or backings with the occasional weak }\end{array}$ & 3 \\
Level IV & $\begin{array}{l}\text { Argumentation shows arguments with a claim with a clearly identifiable } \\
\text { rebuttal. Such an argument may have several claims and counter-claims. }\end{array}$ & 4 \\
Level V & Argumentation displays an extended argument with more than one rebuttal. & 5 \\
\hline
\end{tabular}

For the analysis of data generated during the process of argumentation by pre-service science teachers of low, middle and high groups; these methods were followed respectively:

1. Argumentations made by the groups, which were digitally recorded with sound recorders, were written down separately according to the groups (low-middle-high) and scenarios type.

2. Before starting the argumentation analysis in accordance with the argument evaluation scale, which was consisted of nine forms in total and stated above; a general template was formed in order to determine which argumentation component (claim, data, reason, etc.) would be chosen for which statement written in the form and in what circumstances. A researcher, expert in the field of argumentation analysis, joined to the template formation process. The compromised argument analysis method contains these premises;

a) Provisions about certain situations were accepted as 'claim'.

b) If this claim was supported-explained with conjunctions or transition words like 'because, that's why'; it was accepted as 'warrant'.

c) If the person presented the claim with a de facto knowledge, it was accepted as 'data'. The real point considered here was words like 'for example' and 'for instance'. If the sentence started with these words, it was preferred to mark them as 'data' components.

d) If a claim stated was supported by a second warrant, that second reason was marked as a 'supportive' component. 
e) The point considered for rebuttal was the use of conjunctions like 'but, however' that indicate contradictory or alternative aspects. If the person stated alternative or different aspects of opposite party's ideas by using a conjunction like 'but', it was marked as a 'Rebuttal' component. Two different ways were followed for the 'Rebuttal' component. If the rebuttal was presented with an extra component (e.g. data, reason, supportive), it was called strong rebuttal; it was not supported with an extra component, it was called weak rebuttal.

3. After reaching a consensus on the argumentation analysis method, three of the nine forms, which contain argumentations of the groups (one form from each issue context), were sent to the same researcher and the analysis made in different times and different places on these form were compared. After the comparison, reliability among coders was determined to be $\% 88$. This value received proves the reliability of the coding (Miles \& Huberman, 1994).

4. After ensuring the reliability criteria, argument component identification process was completed by conducting argumentation analysis on the rest of forms.

5. Analyzed statements in the forms were divided in to argumentation sections in order to identify argumentation quality.

6. Nine forms, which contain argumentation sections of low, middle and high group members made upon different scenarios were gathered in three forms which enabled groups to be compared.

7. Argumentation sections gathered in 3 forms were divided into levels according to the rating scale, which was developed by Erduran et al. (2004) and got ready for the quantitative analysis process.

In the process of quantitative analysis, quantitative data gathered were thought to be constant variables for qualitative analysis (Level $I=1$ points, Level $I I=2$ points, Level $I I I=3$ points, Level $I V=4$ points and Level $V=5$ points). Points obtained from data set were determined by Kolmogorov-Smirnov normality test whether they show normal distribution or not. After the normality test, in order to identify the statistical significance of the difference among low-middle-high groups' argumentation quality according to issue context, Kruskal Wallis-H test was conducted (Büyüköztürk, 2012). 


\section{Findings and Comments}

In this section, at first, findings of qualitative analysis, made with a methodological tool which was developed by Erduran et al. (2004), of the participants'socio-scientific argumentations formed within different contexts (Table 4).

Table 4 The Change of Socioscientific Argumentations According to Issue Context

\begin{tabular}{ccccccc}
\hline Levels & Smart Phone & Score & Golden Rice & Score & Electricity Car & Score \\
\hline Level I & 1 & 1 & 0 & 0 & 3 & 3 \\
Level II & 11 & 22 & 6 & 12 & 8 & 16 \\
Level III & 10 & 30 & 12 & 36 & 13 & 39 \\
Level IV & 5 & 20 & 14 & 56 & 6 & 24 \\
Level V & 4 & 20 & 11 & 55 & 9 & 45 \\
\hline Total Score & & $\mathbf{9 3}$ & & $\mathbf{1 6 9}$ & & $\mathbf{1 2 7}$ \\
\hline
\end{tabular}

As it is shown clearly in Table 4, the total score of socio-scientific argumentations formed through the 'golden rice' scenario was determined to be higher than the other two argumentation context. Level IV and Level V argumentations which represent the best quality argumentations were mostly seen in the context of 'Electric Car Production' and 'Golden Rice' scenarios. Level I and Level II argumentations which represent the lowest quality argumentations were mostly seen in the context of 'Electric Car Production', 'Cell phones Are Threatening Human Life' scenarios. The data presented in Table 4 show that as the context of argumentation change, the argumentation formation degree changes too. However, when the total argumentation scores of the scenarios are compared, it can be seen that the argumentation value of 'Electric Car Production', 'Cell phones Are Threatening Human Life' scenarios are very close to each other; on the other hand the value of the arguments within the context of 'Golden Rice' scenario is higher than the others. For a clear understanding of the argumentations made by participants during the socio-scientific argumentation process, an example for each level of argumentation was presented. Quoted passages of pre-service science teachers were presented under names independent of the study in order to hide their identity information.

\section{Level I argumentation (Electric Car)}

In this part of the argumentation, the first person presents data along with a secret claim. On the other hand the other person forms his/her own claim in search of a solution. Afterwards 
other participants tries to make contribution to the argumentation by adding their claims and more data.

A $_{3}$ : I want to say that after all we can't produce oil in our country. As a matter of fact we have to import it.

$\mathbf{B}_{3}$ : Neither electric car nor the usual gasoline car; they must find another solution.

$\mathbf{C}_{3}$ : A flying car with helium gas. If there are flying balloons, why not flying cars?

$\mathbf{B}_{3}$ : Anyway there was a car like that.

$\mathbf{A}_{3}$ : Besides, there are $L P G$ powered cars.

$\left[\operatorname{Data}\left(\mathbf{A}_{3}\right)+\right.$ Claim $\left(\mathbf{B}_{3}\right)+$ Claim $\left(\mathbf{C}_{3}\right)+$ Claim $\left.\left(\mathbf{B}_{3}\right)+\operatorname{Data}\left(\mathbf{A}_{3}\right)\right]$

\section{Level II argumentation (Smart Phones)}

In this part of argumentation where there is an agreement between the two participants, the first participant tries to back up his/her claim with a warrant and backing components. As a response the second participant presents a reasoned claim and shows her/his agreement.

$\mathbf{A}_{2}$ : I don't say cell-phones should not be used, but its use should be reduced; because sometimes people carry even two or three cell-phones at the same time. While one cell-phone is so harmful for the brain, we can't imagine how harmful a few can be. Already we have been living exposed to radiation all day.

$\mathbf{B}_{2}$ : Yes, we have to use technological devices, but cell-phone is not a must. How could people communicate before cell-phones? They managed it somehow.

$\left[\right.$ Claim + Warrant + Backing $\left.\left(\mathbf{A}_{2}\right)\right]+\left[\right.$ Claim + Warrant $\left.\left(\mathbf{B}_{2}\right)\right]$

\section{Level III argumentation (Golden Rice)}

In this part of argumentation two participants present arguments as response to each other. This part where there are only claims, data, weak rebuttals; can be summarized as below.

$\mathbf{B}_{1}$ : For example I meant to say that there aren't any vegetables in Japan.

$\mathbf{C}_{1}$ : Then, you send another alternative

$\mathbf{B}_{1}$ : I send another alternative now, but

$\mathbf{C}_{1}$ : Not exportation from abroad.

$\mathbf{B}_{1}$ : So rare.

$\mathbf{C}_{1}$ : Okay, it can't be so difficult to reach these.

$\mathbf{B}_{1}$ : Very difficult, the price of just one tomato is at least 5 liras.

$\mathbf{C}_{1}$ : You shouldn't take this just for Japan.

B1: You can't reach them, think it that way. Instead it gives you the chance to use what you have with reinforcements.

[Data $\left.\left(\mathbf{B}_{1}\right)\right]+\left[\right.$ Rebuttal $($ Weak $\left.)\left(\mathbf{C}_{1}\right)\right]+\left[\right.$ Claim $\left.\left(\mathbf{B}_{1}\right)\right]+\left[\right.$ Rebuttal (Weak) $\left.\left(\mathbf{C}_{1}\right)\right]+\left[\right.$ Claim $\left.\left(\mathbf{B}_{1}\right)\right]+\left[\right.$ Claim $\left.\left(\mathbf{C}_{1}\right)\right]$ $+\left[\right.$ Rebuttal $($ Weak $\left.)\left(B_{1}\right)\right]+\left[\right.$ Rebuttal $($ Weak $\left.)\left(C_{1}\right)\right]+\left[\right.$ Rebuttal $($ Weak $\left.)\left(B_{1}\right)\right]$ 


\section{Level IV argumentation (Electric Car)}

In this part of argumentation which was formed in accordance with the scenario related to electric car usage, we can see that there is an increase in opposing claims and persuasion processes. The first participant presents his/her claim with a data backup, and the other participant takes his/her position with another claim. On the other hand another participant tries to falsify the claims with a weak rebuttal. The last participant's strong rebuttal which is presented with data makes this argumentation Level IV.

D $_{1}$ : You don't give enough credit to air pollution, but when the air is polluted water will get polluted too; you don't consider that.

$\mathbf{A}_{\mathbf{1}}$ : But, in any case there will be air-pollution.

$\mathbf{C}_{1}$ : When we run out of the oil that we have, what will we do?

$\mathbf{B}_{1}$ : But there are things polluting the air other than oil, oil usage is not the only cause.

$\mathbf{D}_{1}$ : Yes, but the most important cause of air-pollution is the exhaust gas.

$\mathbf{C}_{1}$ : Why do we think about things like these, when the apocalypse is so soon to happen.

$\left[\right.$ Claim + Data $\left.\left(\mathbf{D}_{1}\right)\right]+\left[\right.$ Claim $\left.\left(\mathbf{A}_{1}\right)\right]+\left[\right.$ Rebuttal $($ Weak $\left.)\left(\mathbf{C}_{1}\right)\right]+\left[\right.$ Rebuttal $($ Strong $)\left(\mathbf{B}_{1}\right)+$ Data $]+\left[\right.$ Claim $\left.\left(\mathbf{D}_{1}\right)\right]$ $+\left[\right.$ Claim $\left.\left(\mathbf{C}_{1}\right)\right]$

\section{Level Vargumentation (Smart Phones)}

In this argumentation part, the first participant states a reasoned claim. The opposite party responds with a weak rebuttal. In this part, where all the participants present opposing arguments, the third participant responds with a weak rebuttal, too. The fourth participant's argument is a weak rebuttal, too. At the end, the last participant presents an strong rebuttal, so that, this part of the argument contains more than one rebuttal and becomes a Level $\mathrm{V}$ argumentation.

$\mathbf{B}_{1}$ : For instance if there hadn't been smart phones when you were born, you wouldn't need them; you would know how to live without them, but they exist.

$\mathbf{D}_{1}$ : OK, but, we don't have to go on living with them since there are phones in today's technology.

A: But you are used to arranging everything with your cell-phone; suppose how hard would it be,

if, suddenly, you had to use letters and telegraphs again!

$\mathbf{C}_{1}$ : It shouldn't have to be suddenly, you stop using something when you have other things to substitute it.

$\mathbf{D}_{\mathbf{1}}$ : Bui it is not a necessity like eating or drinking. You can go on living without it.

$\mathbf{A}_{1}$ : Being social and satisfying social needs are as necessary as eating or drinking. For a person to be happy, talking to another person, going out with them are as important as eating and drinking.

[Claim + Warrant $\left.\left(\mathbf{B}_{1}\right)\right]+\left[\right.$ Rebuttal (Weak) $\left.\left(\mathbf{D}_{1}\right)\right]+\left[\right.$ Rebuttal $($ Weak $\left.)\left(\mathbf{A}_{1}\right)\right]+\left[\right.$ Rebuttal $($ Weak $\left.)\left(\mathbf{C}_{1}\right)\right]+$ [Rebuttal (Strong) + Warrant $\left.\left(\mathbf{D}_{1}\right)\right]+\left[\right.$ Rebuttal (Strong) + Warrant $\left.\left(\mathbf{A}_{1}\right)\right]$ 


\section{Quantitative Analysis of the Change of Socio-scientific Argumentation Quality According to the Context}

Statistical significance was examined by the quantification of the argumentation episodes, which were formed according to specific scenarios, in order to reinforce the qualitative data collected to show the change of argumentation quality in relation to the context. At this point, first of all, in order to see whether the scores obtained from the data sets show normal distribution or not, kolmogorov-smirnov normality test was conducted.

Table 5 Kolmogorov-Smirnov Normality Results

\begin{tabular}{lccccc}
\hline & $\mathbf{N}$ & $\overline{\mathbf{X}}$ & S.D. & $\mathbf{Z}$ & $\mathbf{p}$ \\
\hline Argumentation Episodes & 113 & 3,35 & 1,15 &, 187 &, 000 \\
\hline
\end{tabular}

$p \overline{p<, 05}$

According to Table 5, the data collected from the study group (argumentation episodes) were determined not to have a normal distribution $(p<, 05)$. This means that nonparametric tests can be conducted on the data. As a result the significance of the influence of the context on preservice science teachers' socio-scientific argumentation quality was determined by Kruskal Wallis H-Test.

Table 6 Kruskal Wallis H-Test Results

\begin{tabular}{lccccc}
\hline Scenarios & N & Mean Rank & df & $\mathbf{x}^{\mathbf{2}}$ & $\mathbf{p}$ \\
\hline Smart Phone & 31 & 46,79 & 2 & 7,294 &, 026 \\
Golden Rice & 43 & 66,52 & & & \\
Electricity Car & 39 & 54,62 & & & \\
\hline
\end{tabular}

Kruskal Wallis H-Test results that show the statistical significance of the change of preservice science teachers' argumentation quality according to the context were presented in Table 6. The participants were divided into three groups, each consisting four members, as Low-Middle-High according to their nature of science understandings. The analysis results show that the quality of argumentation shows , 05 differentiation according to the context [x2 $(2)=7,294, p<, 05]$. This finding represents that there is a significant difference between the mean ranks of the argumentations formed in accordance with the scenarios. When their mean ranks are considered the best quality argumentation was formed within the context of 'Golden 
Rice' scenario; and it was followed respectively by 'Electric Cars' and 'Smart Phones'. In short Kruskall Wallis H-test results showed that the context significantly affects pre-service science teachers' socio-scientific argumentation qualities.

\section{Conclusion and Discussion}

In this study which was conducted in order to determine the influence of the context on pre-service science teachers' socio-scientific argumentation qualities, it was determined that there is a significant difference between the two variables. The findings of the qualitative analysis of the socio-scientific argumentations formed with scenarios about electric cars, smart phones and golden rice reveal that the better quality of argumentations was reached especially with the 'Golden Rice' scenario (Table 4). This finding proves the claim that the context of argumentation significantly affects pre-service science teachers' socio-scientific argumentation qualities. The change of argumentation scores in relation to the context backs up this claim (e.g., Dawson \& Venville, 2010; Molinatti et al., 2010; Khishfe, 2012b). In order to investigate this claim thoroughly argumentations formed in accordance with the other scenarios were also examined qualitatively and they were determined to have close quality levels. For example, as it is seen in Table 4, while the numbers of Level IV and Level V argumentations formed according to 'Smart Phone' scenario are respectively ' 5 ' and ' 4 '; the numbers of the same level argumentation are respectively ' 6 ' and ' 9 ' in relation to 'Electric Cars' scenario. The numbers being so close to each other in different scenarios is a highly remarkable finding. Their total argumentation scores being so close to each other is another remarkable point as well (Smart Phones:93, Electric Cars: 127). In order to support qualitative results that had been obtained; qualitative data were transformed to quantitative data and Kruskal Wallis H-test was conducted on these quantitative data. The analysis results show that the quality of argumentation shows ,05 differentiation according to the context $[\mathrm{x} 2(2)=7,294, \mathrm{p}<, 05]$. This finding represents that there is a significant difference between the mean ranks of the argumentations formed in accordance with the scenarios. According to this the mean ranks of 'Smart Phones', 'Electric Cars' and 'Golden Rice' scenarios are increasing respectively; '46,79'; '54,62' and '66,52'. From the mean ranks of the scenarios it can be seen that the argumentations formed according to 'Smart Phones' and 'Electric Cars' are again so close to each other, while the argumentations of 'Golden Rice' scenario differ highly from them. There are also studies that do not confirm the results of this study (Albe, 2008; Khishfe, 2012b; Molinatti et al., 2010; Topçu, et al., 2010). 
In those studies the context of the argumentation does not have any impact on the decision making process. The reasons of the nonconformance can be listed as below:

- The context quality: The reason of this study's findings to be different from the findings of some studies in literature may be the different handling of the contexts that are being compared. For instance, Molinatti et al., (2010) compared stem cell applications and gene therapy; ; Khishfe, (2012b) compared genetically modified organisms and water fluoridation; and Topçu et al. (2010) compared gene therapy, cloning, and global warming. However, in this study smart phones, electric cars and golden rice scenarios, which highly differ from each other with regar to the disciplines, were compared.

- The number of participants: This study was conducted with 12 participants whom were chosen among 27 third grade pre-service science teachers who were studying in a science education program of a state university; and concluded that the context influences the quality of socio-scientific argumentation. The studies, whose results contradict with this study, were conducted more participants; Molinatti et al. (2010) 196 participants, Topçu et al. (2010) 39 participants, Khishfe (2012b) 219 participants.

- Grade levels of the participants: This study was conducted with 12 third grade preservice science teachers who were studying in a science education program of a state university; however, the contradictory studies were conducted mostly with high school students (Albe, 2008; Molinatti et al., 2010; Khishfe, 2012b).

This study showed that the argumentations which were formed by 12 pre-service science teacher according to three different scenarios (Golden Rice, Electric Cars and Smart Phones) during the argumentation process, significantly differed from each other. The cause of this result was thoroughly explained in the light of current literature. As it is known, socio-scientific issues focus on social issues which consist an ethical or moral component with a scientific concern. The contexts used in this study may be serving to the nature of socio-scientific issues at different levels (Sadler \& Fowler, 2006). This situation may be a point which can explain the change of socio-scientific argumentation quality according to the context. On the other hand, Zeidler et al. (2005) claimed that science content understanding of a person, and personal and social reflections on the belief based knowledge field may affect evaluation of socio-scientific issues. This claim is favoring the findings (contextual effects on the socio-scientific argumentation quality) of this study. Along with this a lot of researchers stated that personal experiences affect informal reasonings related to socio-scientific issues. And this shows that the change of socio-scientific argumentation quality may be resulted from the difference of 
personal experiences. Sadler and Zeidler, (2005) stated that socio-scientific issues have technological, methodological, and conceptual contradictions. According to the researchers socio-scientific issues related to biotechnological applications, environmental problems, and human genetics have resulted in contradictions of different levels. This aspect of socioscientific issues may be one of the reasons that explain the change of argumentation quality in relation to the context.

The findings of this study and stated facts in the literature clarify that more studies related to this field of research should be conducted. For this reason, in order to support the literature, more studies can be conducted with pre-service science teachers without making any change in content. Especially, for the researchers who include pre-service teachers and students to socioscientific argumentation process, they may need to consider personal experiences; technological, methodological, and conceptual basis of the subject while deciding on the context. In addition to this, in the possible future studies, using a variety of contexts may be a good advice for the sake of literary contribution. And, lastly, in so as to improve the quality of education and to raise science-literate future generations, a particular importance may be attached to education processes including socio-scientific issues.

\section{References}

Albe, V. (2008). When scientific knowledge, daily life experience, epistemological and social considerations intersect: students ' argumentation in group discussion on a socio-scientific issue. Research in Science Education, 38, 67-90.

American Association for the Advancement of Science. (2001). Designs for science literacy. New York: Oxford University Press.

Bell, R. L. \& Lederman, N. G. (2003). Understandings of the nature of science and decision making on science and technology based issues. Science Education, 87, 352-377.

Büyüköztürk, S. (2012). Sosyal bilimler için veri analizi el kitabı. 16. Bask1, Ankara: Pegem Akademi.

Cresswell, J. W. (2008). Educational research: planning, conducting and evaluating quantitative and qualitative research. New Jersey: Pearson.

Çetin, P. S., Erduran, S. ve Kaya, E. (2010). Understanding the nature of chemistry and argumentation: the case of pre-service chemistry teachers. Ahi Evran Üniversitesi Kırşehir Eğitim Fakültesi Dergisi, 11(4), 41-59. 
Dawson, V. M. \& Venville, G. (2010). Teaching strategies for developing students' argumentation skills about socioscientific 1ssues in high school genetics. Research in Science Education, 40, 133-148.

Dawson, V. (2015). Western australian high school students' understandings about the socioscientific 1ssue of climate change. International Journal of Science Education, 37(7), 1024-1043.

Driver, R., Newton, P., \& Osborne J. (2000). Establishing the norms of scientific argumentation in classrooms. Science Education, 84, 287-312.

Erduran, S., Simon, S., \& Osborne, J. (2004). TAPping into argumentation: Developments in the application of Toulmin's argument pattern for studying science discourse. Science Education, 88, 915-933.

Eş, H., Işık-Mercan, S. ve Ayas, C. (2016). Türkiye için yeni bir sosyo-bilimsel tartışma: Nükleer ile yaşam. Turkish Journal of Education, 5(2), 47-59.

Fraenkel, J. R., Wallen, N. E., \& Hyun, H. H. (2006). How to design and evaluate research in education. 8. Bask1, New York: McGraw-Hill.

Giannakaki, M. S. (2005). Using mixed-methods to examine teachers' attitudes to educational change: the case of the skills for life strategy for improving adult literacy and numeracy skills in england. Educational Research and Evaluation, 11(4), 323-348.

Glaser, B. G. \& Strauss, A. L. (1967). The discovery of grounded theory. Chicago: Aldine.

Herman, B. C. (2015). The influence of global warming science views and sociocultural factors on willingness to mitigate global warming. Science Education, 99, 1-38.

Iordanou, K. \& Constantinou, C. P. (2014). Developing pre-service teachers' evidence-based argumentation skills on socio-scientific issues. Learning and Instruction, 34, 42-57.

Kara, Y. (2012). Pre-service biology teachers' perceptions on the instruction of socio-scientific issues in the curriculum. European Journal of Teacher Education, 35(1), 111-129.

Khishfe, R. (2012a). Nature of science and decision making. International Journal of Science Education, 34(1), 67-100.

Khishfe, R. (2012b). Relationship between nature of science understandings and argumentation skills: A role for counterargument and contextual factors. Journal of Research in Science Teaching, 49(4), 489-514. 
Kırbağ Zengin, F., Keçeci, G. ve Kırılmazkaya, G. (2012). ilköğretim öğrencilerinin nükleer enerji sosyo-bilimsel konusunu online argümantasyon yöntemi ile öğrenmesi. NWSAEducation Sciences, 7(2), 647-654.

Köseoğlu, F., Tümay, H. ve Üstün, U. (2010). Bilimin doğası öğretimi mesleki gelişim paketinin geliştirilmesi ve öğretmen adaylarına uygulanması ile ilgili tartışmalar. Ahi Evran Ünv. Kırşsehir Ĕ̈itim Fakültesi Dergisi, 11(4),129-162.

Liu, S. Y., Lin, C. S., \& Tsai, C. C. (2011). College students' scientific epistemological views and thinking patterns in socioscientific decision making. Science Education, 95, 497-517.

Miles, M. B. \& Huberman, A. M. (1994). Qualitative data analysis: An expanded sourcebook. Thousand Oaks, CA: Sage Publications.

Milli Eğitim Bakanlığ1 (MEB) (2013). İlköğretim fen ve teknoloji dersi (3-8. sinıflar) öğretim programı, Milli Eğitim Bakanlığı Yayınları, Ankara.

Molinatti, G., Girault, Y., \& Hammond, C. (2010). High School Students Debate the Use of Embryonic Stem Cells: The influence of context on decision-making. International Journal of Science Education, 32(16), 2235-2251.

National Research Council. (2013). A framework for K-12 science education: Practices, crosscutting concepts, and core ideas. Washington, DC: The National Academies Press.

Nielsen, J. A. (2012). Arguing from Nature: The role of 'nature' in students' argumentations on a socio-scientific issue. International Journal of Science Education, 34(5), 723-744.

Onwuegbuzie, A. J. \& Leech, N. L. (2004). Enhancing the interpretation of significant findings: the role of mixed methods research. The Qualitative Report, 9(4): 770-792.

Osborne, J., Erduran S., \& Simon, S. (2004). Enhancing the Quality of Argumentation in School Science. Journal of Research in Science Teaching, 41(10), 994-1020.

Sadler, T. D., Chambers, F. W., \& Zeidler, D.L. (2004). Student conceptualisations of the nature of science in response to a socio-scientific issue. International Journal of Science Education, 26(4), 387-409.

Sadler, T. D. \& Donnelly, L. A. (2006). Socioscientific argumentation: The effects of content knowledge and morality. International Journal of Science Education, 28(12), 1463-1488.

Sadler, T. D. \& Fowler, S. R. (2006). A threshold model of content knowledge transfer for socioscientific argumentation. Science Education, 90, 986-1004.

Necatibey Eğitim Fakültesi Elektronik Fen ve Matematik Eğitimi Dergisi

Necatibey Faculty of Education, Electronic Journal of Science and Mathematics Education 
Salvato, E. \& Testa, I. (2012). Improving students' use of content knowledge when dealing with Socio-Scientific Issues: the case of a physics-based inter-vention. Quaderni di Ricerca in Didattica, 3, 15-36.

Sampson, V. \& Clark, D. (2006). The development and validation of the nature of science as argument questionnaire (NSAAQ). International Conference of the National Association of Research in Science Teaching (NARST), San Francisco.

Simon, S. \& Johnson, S. (2008). Professional learning portfolios for argumentation in school science. International Journal of Science Education, 30, 669-688.

Sullivan, L. E. (2009). The Sage glossary of the social and behavioral sciences. New York: Sage.

Topçu, M. S., Muğaloğlu, E. Z. ve Güven, D. (2014). Fen eğitiminde sosyobilimsel konular: Türkiye örneği. Kuram ve Uygulamada Eğitim Bilimleri, 14(6), 2327-2348.

Topçu, M. S., Sadler, T. D., \& Y1lmaz-Tüzün, Ö. (2010). Preservice science teachers' informal reasoning about socioscientific issues: The influence of issue context. International Journal of Science Education, 32(18), 2475-2495.

Venville, G. \& Dawson, V. M. (2010). The Impact of a classroom intervention on grade 10 students' argumentation skills, informal reasoning, and conceptual understanding of science. Journal of Research in Science Education, 47(8), 952-977.

Yıldırım, A. ve Şimşek, H. (2008). Sosyal bilimlerde nitel araştırma yöntemleri. 7. Baskı. Ankara: Seçkin Yayıncılık.

Zeidler, D. L. \& Nichols, B. H. (2009). Socioscientific Issues: Theory and Practice. Journal of Elementary Science Education, 21(2), 49-58.

Zeidler, D. L., Sadler, T. D., Simmons, M. L., \& Howes, E. V. (2005). Beyond STS: A researchbased framework for socio-scientific issues education. Science Education, 89(3), 357377.

Zohar, A. \& Nemet, F. (2002). Fostering students' knowledge and argumentation skills through dilemmas in human genetics. Journal of Research in Science Teaching, 39, 35-62.

Zohar, A. (2008). Science teacher education and professional development in argumentation. S. Erduran \& M. P. Jimenez-Aleixandre (Eds.), Argumentation in science education: Perspectives from classroom-based research (pp. 245-268). Dordrecht: Springer. 